\title{
The use of nipple shields: a review
}

\author{
Selina Chow ${ }^{1}$, Ronald Chow ${ }^{1}$, Marko Popovic ${ }^{1}$, Henry Lam ${ }^{2}$, Joav Merrick ${ }^{3}$, \\ Søren Ventegodt ${ }^{4 *}$, Milica Milakovic ${ }^{1}$, Michael Lam ${ }^{2}$, Mila Popovic ${ }^{1}$, Edward Chow ${ }^{2}$ \\ and Jelena Popovic ${ }^{1}$

\begin{abstract}
${ }^{1}$ Toronto East General Hospital, Toronto, ON, Canada, ${ }^{2}$ Sunnybrook Health Sciences Centre, Toronto, ON, Canada, ${ }^{3}$ Health Services, Division for Intellectual and Developmental Disabilities, Ministry of Social Affairs, National Institute of Child
\end{abstract} \\ Health and Human Development, Jerusalem, Israel, ${ }^{4}$ Quality of Life Research Center, Copenhagen, Denmark
}

\section{OPEN ACCESS}

Edited by:

Frederick Robert Carrick, Carrick Institute, USA

Reviewed by:

Susan Elizabeth Esposito, Life University, USA Linda Mullin Elkins, Life University, USA

*Correspondence: Søren Ventegodt ventegodt@livskvalitet.org

Specialty section: This article was submitted to Child Health and Human Development, a section of the journal Frontiers in Public Health

Received: 01 September 2015 Accepted: 30 September 2015

Published: 16 October 2015

Citation:

Chow S, Chow R, Popovic M, Lam H, Merrick J, Ventegodt $S$, Milakovic M, Lam M, Popovic M, Chow E and Popovic J (2015) The use of nipple shields: a review. Front. Public Health 3:236. doi: 10.3389/fpubh.2015.00236
Introduction: A nipple shield is a breastfeeding aid with a nipple-shaped shield that is positioned over the nipple and areola prior to nursing. Nipple shields are usually recommended to mothers with flat nipples or in cases in which there is a failure of the baby to effectively latch onto the breast within the first 2 days postpartum. The use of nipple shields is a controversial topic in the field of lactation. Its use has been an issue in the clinical literature since some older studies discovered reduced breast milk transfer when using nipple shields, while more recent studies reported successful breastfeeding outcomes. The purpose of this review was to examine the evidence and outcomes associated with nipple shield use.

Methods: A literature search was conducted in Ovid MEDLINE, OLDMEDLINE, EMBASE Classic, EMBASE, Cochrane Central Register of Controlled Trials, and CINAHL. The primary endpoint was any breastfeeding outcome following nipple shield use. Secondary endpoints included the reasons for nipple shield use and the average/median length of use. For the analysis, we examined the effect of nipple shield use on physiological responses, premature infants, mothers' experiences, and health professionals' experiences.

Results: The literature search yielded 261 articles, 14 of which were included in this review. Of these 14 articles, three reported on physiological responses, two reported on premature infants, eight reported on mothers' experiences, and one reported on health professionals' experiences.

Conclusion: Through examining the use of nipple shields, further insight is provided on the advantages and disadvantages of this practice, thus allowing clinicians and researchers to address improvements on areas that will benefit mothers and infants the most.

Keywords: nipple shield, breastfeeding, lactation

\section{INTRODUCTION}

The immunologic and anti-infective properties of breast milk are advantageous to babies, particularly high-risk premature infants (1). Moreover, breastfeeding establishes important emotional and bonding experiences for the mother-infant dyad (2).

Since breastfeeding confers benefits to both mothers and infants, it is necessary to promote breastfeeding and mitigate barriers that may prevent its success and/or lead to early breastfeeding 
termination (3). For example, the reluctant or non-nursing infant is an overwhelming challenge to a new mother (4). Many women in this situation wean their breastfeeding efforts due to the absence of timely help or the lack of resources/support (4). When maternal and/or infant-related factors challenge breastfeeding, nipple shields may preserve and facilitate breastfeeding (3).

A nipple shield is a breastfeeding aid with a nipple-shaped shield that is positioned over the nipple and areola prior to nursing (3). Nipple shields are usually recommended to mothers for flat nipples or in cases in which there is a failure of the baby to effectively latch onto the breast within the first 2 days postpartum. They are also used for sore nipples, prematurity, oversupply, transitioning infants from the bottle to the breast, and other indications (5).

The physical design of the shield has drastically changed over time, dating back to the sixteenth century (6). Nipple shields have progressed from being made of lead, wax, silver, wood, pewter, and animal skins, to rubber, thin latex, and today's silicone models (5-7).

In order to use a nipple shield effectively, it should correctly fit the mother's breast, and the infant should be latched onto the entire areola, not just the shield's tip. The shield needs to be positioned over the center of the nipple. A series of clockwise rotations should then guide the nipple into the shield tunnel and stretch the shield's base around the areola. Each stretch of the shield draws more nipple tissue into the shield. The edges of the shield circumference can be secured over the areola with a few drops of water. If the infant is latched onto the shield properly, each suck will show visible movements in the area of the breast distal to the shield. In contrast, little or no breast movement is visible with sucking if the infant is only on the tip of the nipple shield (8).

The use of nipple shields is a controversial topic in lactation. Its use has been an issue in the clinical literature since some older studies discovered reduced breast milk transfer when using nipple shields (9-12). Nonetheless, more recent studies have reported successful breastfeeding outcomes following the use of nipple shields $(4,7,13-18)$.

Nipple shields are not only debated among healthcare professionals but also among mothers. The shields may act as a solution to a problem, thus reducing the stress from breastfeeding difficulties, or it may increase stress when women aim to breastfeed without accessories (18). To provide a foundation of evidence for the use of nipple shields, this review was undertaken to evaluate the evidence and outcomes associated with nipple shield use.

\section{METHODS}

A literature search was conducted in Ovid MEDLINE and OLDMEDLINE (1946 to June Week 3 2015), EMBASE Classic and EMBASE (1947 to 2015 Week 26), Cochrane Central Register of Controlled Trials (up until May 2015), and CINAHL (up until July 1, 2015). A full list of search terms is provided in Figures 1-4. Titles and abstracts were screened to identify if studies were relevant for full-text screening, after which full texts were included if they met the pre-specified inclusion criteria.

Ovid MEDLINE(R) and Ovid OLDMEDLINE(R) <1946 to June Week $32015>$
\begin{tabular}{|l|l|l|}
\hline \multicolumn{1}{|c|}{ Search Statement } & Results \\
\hline 1 & exp Nipples/ & 3932 \\
\hline 2 & exp Breast Feeding/ & 27184 \\
\hline 3 & exp Lactation/ & 34007 \\
\hline 4 & exp Protective Devices/ & 33377 \\
\hline 5 & (mexican hat or thin latex or cannon babysafe).mp. & 119 \\
\hline 6 & (nipple adj3 shield*).mp. & 59 \\
\hline 7 & (4 or 5) and (1 or 2 or 3) & 48 \\
\hline 8 & 6 or 7 & 78 \\
\hline 9 & limit 8 to (english language and humans) & 68 \\
\hline
\end{tabular}

FIGURE 1 | Search strategy for Ovid MEDLINE and OLDMEDLINE.

\begin{tabular}{|c|c|c|}
\hline \multicolumn{3}{|c|}{ Embase Classic+Embase $<1947$ to 2015 Week 26> } \\
\hline$\#$ & Search Statement & Results \\
\hline 1 & exp nipple/ & 7195 \\
\hline 2 & exp breast feeding/ & 38647 \\
\hline 3 & exp lactation/ & 44159 \\
\hline 4 & exp lactation disorder/ & 1740 \\
\hline 5 & exp lactation consultant/ & 143 \\
\hline 6 & exp protective equipment/ & 40250 \\
\hline 7 & (mexican hat or thin latex or cannon babysafe).mp. & 175 \\
\hline 8 & $(6$ or 7$)$ and $(1$ or 2 or 3 or 4 or 5$)$ & 132 \\
\hline 9 & (nipple adj3 shield*).mp. & 77 \\
\hline 10 & 8 or 9 & 183 \\
\hline 11 & limit 10 to (human and english language) & 151 \\
\hline
\end{tabular}

FIGURE 2 | Search strategy for EMBASE Classic and EMBASE.

\begin{tabular}{|c|c|c|}
\hline \multicolumn{3}{|c|}{ EBM Reviews - Cochrane Central Register of Controlled Trials $<$ May 2015> } \\
\hline \# & Search Statement & Results \\
\hline 1 & exp Nipples/ or nipple*.mp. & 277 \\
\hline 2 & exp Breast Feeding/ or breast feeding.mp. & 1868 \\
\hline 3 & exp Lactation/ or lactation.mp. & 1045 \\
\hline 4 & exp Protective Devices/ or (protective device* or protective equipment*).mp. & 2044 \\
\hline 5 & (mexican hat or thin latex or cannon babysafe).mp. & 2 \\
\hline 6 & (nipple adj3 shield*).mp. & 9 \\
\hline 7 & $(4$ or 5$)$ and ( 1 or 2 or 3$)$ & 6 \\
\hline 8 & 6 or 7 & 12 \\
\hline 9 & limit 8 to english language & 11 \\
\hline
\end{tabular}

\section{Selection Criteria}

Articles were selected for full-text screening if the title or abstract mentioned nipple shield(s). Only English language studies were included. Duplicates of articles found in each database, as well as non-original research, small (i.e., $<5$ patients) sized studies, and 


\begin{tabular}{|c|c|c|c|c|}
\hline $\begin{array}{c}\text { Search } \\
\text { ID\# }\end{array}$ & Search Terms & Search Options & Last Run Via & Results \\
\hline S8 & TX (nipple N3 shield*) & $\begin{array}{l}\text { Limiters - English Language } \\
\text { Search modes - Boolean/Phrase }\end{array}$ & $\begin{array}{l}\text { Interface - EBSCOhost Research Databases } \\
\text { Search Screen - Advanced Search } \\
\text { Database - CINAHL }\end{array}$ & 31 \\
\hline S7 & S6 AND (S1 OR S2 OR S3 OR S4 OR S5) & Search modes - Boolean/Phrase & $\begin{array}{l}\text { Interface - EBSCOhost Research Databases } \\
\text { Search Screen - Advanced Search } \\
\text { Database - CINAHL }\end{array}$ & 0 \\
\hline S6 & $\begin{array}{l}\text { TX (protective device OR protective } \\
\text { equipment OR mexican hat OR think latex } \\
\text { OR cannon babysafe) }\end{array}$ & Search modes - Boolean/Phrase & $\begin{array}{l}\text { Interface - EBSCOhost Research Databases } \\
\text { Search Screen - Advanced Search } \\
\text { Database - CINAHL }\end{array}$ & 813 \\
\hline S5 & (MH "Lactation Disorders+") & Search modes - Boolean/Phrase & $\begin{array}{l}\text { Interface - EBSCOhost Research Databases } \\
\text { Search Screen - Advanced Search } \\
\text { Database - CINAHL }\end{array}$ & 536 \\
\hline S4 & (MH "Lactation Consultants") & Search modes - Boolean/Phrase & $\begin{array}{l}\text { Interface - EBSCOhost Research Databases } \\
\text { Search Screen - Advanced Search } \\
\text { Database - CINAHL }\end{array}$ & 404 \\
\hline S3 & (MH "Lactation") & Search modes - Boolean/Phrase & $\begin{array}{l}\text { Interface - EBSCOhost Research Databases } \\
\text { Search Screen - Advanced Search } \\
\text { Database - CINAHL }\end{array}$ & 1,660 \\
\hline S2 & (MH "Breast Feeding+") & Search modes - Boolean/Phrase & $\begin{array}{l}\text { Interface - EBSCOhost Research Databases } \\
\text { Search Screen - Advanced Search } \\
\text { Database - CINAHL }\end{array}$ & 12,379 \\
\hline S1 & (MH "Nipples") & Search modes - Boolean/Phrase & $\begin{array}{l}\text { Interface - EBSCOhost Research Databases } \\
\text { Search Screen - Advanced Search } \\
\text { Database - CINAHL }\end{array}$ & 459 \\
\hline
\end{tabular}

FIGURE 4 | Search strategy for CINAHL.

research on nipple shield use for anything other than breastfeeding (e.g., delivery system for antiviral agents preventing HIV transmission, reconstructive surgery, cancer treatment) were excluded.

\section{Data Extraction and Endpoints}

The primary endpoint was any breastfeeding outcome following nipple shield use. Secondary endpoints included the reasons for nipple shield use and the average/median length of use. For the analysis, we examined the effect of nipple shield use on physiological responses, premature infants, mothers' experiences, and health professionals' experiences.

\section{RESULTS}

The literature search yielded 261 articles, of which 68 were from MEDLINE, 151 from EMBASE, 11 from Cochrane Central, and 31 from CINAHL. Of those, 31 articles were identified for full-text review as specified by the inclusion criteria; 17 of the 31 articles were rejected after full-text review. Some of the reasons for exclusion were the lack/absence of relevant information regarding breastfeeding outcomes with nipple shield use as well as editorials and case reports. Of the 14 remaining articles $(2-4,7,9$, $10,12-14,16-20)$, three reported on physiological responses ( 9 , $10,12)$, two reported on premature infants $(2,16)$, eight reported on mothers' experiences $(3,4,7,13,14,17-19)$, and one reported on health professionals' experiences (20).

\section{Physiological Responses}

Three studies reported on the physiological responses during breastfeeding with a nipple shield $(9,10,12)$.
Amatayakul et al. (10) randomly assigned 50 Northern Thai women to one of three groups: group 1 (16/50) breastfed without a thin latex nipple shield, group $2(16 / 50)$ breastfed with a thin latex nipple shield, and group $3(18 / 50)$ wore a thin latex nipple shield but did not breastfeed. At 1 week postpartum, prolactin and cortisol levels, infant suckling time, and milk transfer were measured with and without a nipple shield. Based on blood samples collected before, during, and after the feeding, no significant differences in either hormone levels were found between groups 1 and 2 (prolactin $-p=0.83$; cortisol $-p>0.1$ ). Use of the nipple shields when breastfeeding had significantly reduced milk transfer, from a median of $47 \mathrm{~g}$ in group 1 to a median of $27 \mathrm{~g}$ in group 2, which was likely due to the inhibition of oxytocin release in group 2 mothers (10) (Table 1).

Auerbach (12) also examined milk transfer with a nipple shield. Twenty-five mothers participated in two separate pumping sessions, one for each breast, where different designs of nipple shields were tested. The "old" shield was the Cannon Babysafe (Glemsford, UK) with four small holes, and the "new" shield was the modified design with one hole. Pumping without a shield yielded larger amounts of milk, with mean volumes six times greater than when the old shield was used and more than four times greater than when the new shield was in place. Evidently, the new shield seemed to reduce the milk volume slightly less than the old shield ( $17 \%$ versus $12 \%$ of overall volume), although this difference was not statistically significant (12) (Table 1).

Woolridge et al. (9) compared the Mexican Hat nipple shield and the thin latex nipple shield with 16 and 18 mother-infant dyads, respectively, at $5-8$ days postpartum. It was found that both nipple shields reduced milk transfer: the Mexican Hat decreased milk supply by $58 \%$, with a mean volume of $19.5 \mathrm{~g}$ compared to a mean volume of $46.4 \mathrm{~g}$ without a shield, whereas the thin latex 
TABLE 1 | Physiological responses with nipple shield use.

\begin{tabular}{|c|c|c|c|}
\hline Author & Study population & Methods & Outcomes \\
\hline $\begin{array}{l}\text { Amatayakul } \\
\text { et al. (10) }\end{array}$ & $\begin{array}{l}\text { - } 50 \text { Northern Thai women } \\
\text { - Were patients at the delivery } \\
\text { wards of the University } \\
\text { Hospital, Chiang Mai, or from } \\
\text { the Mother and Child Health } \\
\text { Centre } \\
\text { - Inclusion criteria } \\
\text { - Were breastfeeding } \\
\text { - } \text { satisfactorily } \\
\text { - } \text { previous child } \\
\text { - Normal labor } \\
\text { - No complications after } \\
\text { - } \text { delivery } \\
\text { Baby was healthy and free } \\
\text { from complications } \\
\text { Baby weighed } \\
\text { 3000-3500 g }\end{array}$ & $\begin{array}{l}\text { - Randomly assigned to } 1 \text { of } 3 \text { groups } \\
\text { - Group } 1(16 / 50) \text { breastfed without a } \\
\text { nipple shield } \\
\text { - } \text { Group } 2(16 / 50) \text { breastfed with the } \\
\text { nipple shield } \\
\text { - Group } 3(18 / 50) \text { wore a nipple shield } \\
\text { but did not breastfeed } \\
\text { - If babies were nursed in the study, they } \\
\text { - were only fed on the left breast } \\
\text { Measured prolactin and cortisol levels, } \\
\text { infant suckling time, and milk transfer } \\
\text { by test weighing with and without a thin } \\
\text { latex nipple shield at } 1 \text { week postpartum }\end{array}$ & 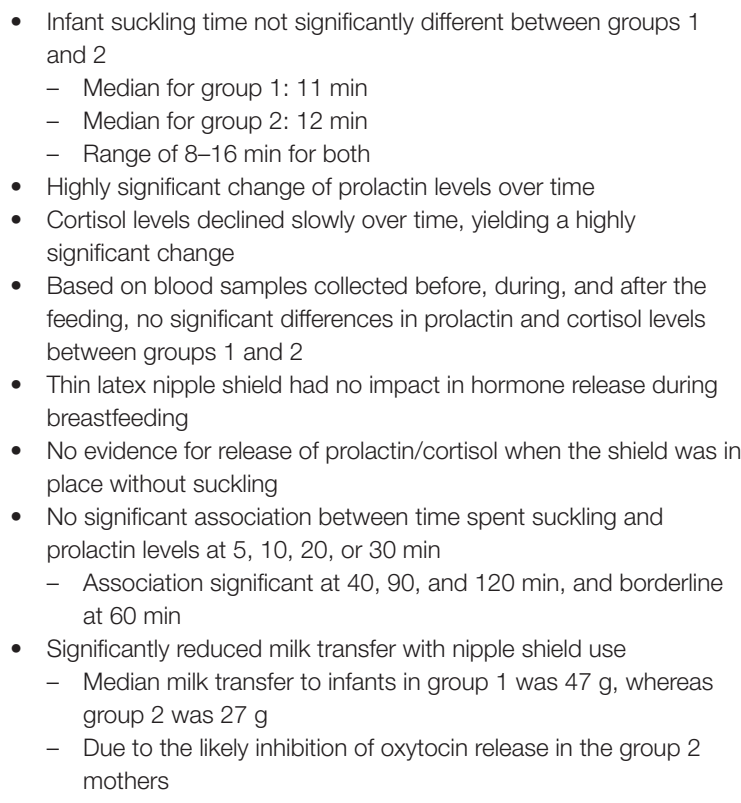 \\
\hline $\begin{array}{l}\text { Auerbach } \\
(12)\end{array}$ & $\begin{array}{l}\text { - } 25 \text { women with well- } \\
\text { established lactation courses } \\
\text { and thriving infants } \\
\text { - Women who were pumping } \\
\text { their breasts during/in } \\
\text { anticipation of employment- } \\
\text { related absences }\end{array}$ & $\begin{array}{l}\text { - Each study subject participated in } 2 \\
\text { different pumping sessions } \\
-\quad 1 \text { session involved } 3 \text { separate } \\
\text { pumping periods on the right breast, } \\
\text { each separated by a 5-min resting } \\
\text { period } \\
-\quad \text { The same was done on the left } \\
\text { breast for the other session } \\
\text { - Pumping regimens consisted of } 3 \\
\text { consecutive 5-min periods per breast } \\
\text { - Without nipple shield } \\
\text { - With old design of shield } \\
\text { - } \quad \text { With new design of shield } \\
\text { Milk was pumped from the breast by a } \\
\text { standard size, high-quality, intermittent } \\
\text { electric pump }\end{array}$ & $\begin{array}{l}\text { - Pumping without a shield resulted in mean volumes } 6 \text { times } \\
\text { greater than when the old shield was used and } 4 \text { times greater } \\
\text { than when the new shield was used } \\
\text { - The new shield appeared to negatively affect milk volume slightly } \\
\text { less than the old shield } \\
\text { - } 17 \text { versus } 12 \% \text { of overall volume }\end{array}$ \\
\hline $\begin{array}{l}\text { Woolridge } \\
\text { et al. (9) }\end{array}$ & $\begin{array}{l}\text { - Inclusion criteria } \\
-\quad \text { Trouble-free lactation } \\
-\quad \text { Age of babies to be } \\
\quad 5-8 \text { days, inclusive } \\
\text { Mexican Hat } \\
\text { - } 16 \text { mother-infant dyads } \\
\text { Thin latex } \\
\text { - } 18 \text { mother-infant dyads }\end{array}$ & $\begin{array}{l}\text { - Milk intake was assessed from the } \\
\text { baby's weight gain } \\
\text { - Measured by test weighing } \\
\text { - Sucking patterns were determined by } \\
\text { filming the mouth of the baby during } \\
\text { the feed }\end{array}$ & $\begin{array}{l}\text { - Mexican Hat reduced milk transfer by } 58 \% \\
\text { - } \quad \text { Mean volume of } 19.5 \mathrm{~g} \text { compared to a mean volume of } 46.4 \mathrm{~g} \\
\text { - } \quad \text { without a nipple shield } \\
\text { - } \quad \text { Mean volume of } 29.9 \mathrm{~g} \text { compared to a mean volume of } 38.4 \mathrm{~g} \\
\text { - } \text { without a nipple shield } \\
\text { - Hat was in place } \\
\text { - } \quad \text { Mexican Hat increased sucking rate (i.e., mean inter-suck } \\
\text { interval was shorter) and the time spent resting (the length of } \\
\text { the pauses were not increased; there were just more of them) } \\
\text { - Little difference (e.g., sucking frequency or pauses) was observed } \\
\text { when mothers used the thin latex nipple shield }\end{array}$ \\
\hline
\end{tabular}

g, grams.

shield diminished milk intake by $22 \%$ from a mean volume of $38.4 \mathrm{~g}$ without a shield to $29.9 \mathrm{~g}$. Recorded videos of the babies' mouths during the feeding process revealed that infant suckling patterns were significantly altered when a Mexican Hat was in place. This nipple shield design increased sucking rate and the time spent resting. In contrast, minimal differences in sucking frequency and pauses were observed when using the thin latex nipple shield (9) (Table 1).

\section{Premature Infants}

Two studies reported the breastfeeding outcomes with nipple shield use for premature infants $(2,16)$. 
Clum and Primomo (2) performed chart reviews for 15 premature infants who were neonatal intensive care unit (NICU) patients and whose mothers intended to breastfeed. In order to investigate the effect of nipple shield use on milk transfer, the infants' prescribed amount of feeding was compared to their actual intake, which was measured by test weights. It was identified that health professionals usually recommended nipple shields if the neonate had difficulty latching for an average of 5 days. The average gestational age at first nipple shield use was 34.9 weeks, ranging from 33 to 39 weeks. Using a nipple shield, nine infants $(60 \%)$ consumed $50 \%$ or more of the prescribed feeding amount, and six infants consumed between 13 and $28 \%$ of the prescribed feeding amount. Therefore, the majority of patients obtained at least half of the prescribed feeding amount during their first nipple shield use, which is an acceptable amount for preterm babies transitioning from gavage to breast/ bottle-feeding (2) (see Table 2).

Meier et al. (16) performed a retrospective analysis of data for 34 premature infants who were NICU patients and whose mothers had used nipple shields to facilitate milk intake during and/or after each infants' stay in the NICU. This study examined the effect of nipple shields on milk transfer and total duration of breastfeeding. The volume of milk transfer, which was measured by infant test weights, was compared for two consecutive breastfeeding (one with and one without the use of a nipple shield). It was found that poor infant latch [21/34 (61.8\%)], infants falling asleep soon after being positioned at the breast [10/34 (29.4\%)], and maternal nipple discomfort [3/34 (8.8\%)] were all reasons for nipple shield use. When using the shield, all infants consumed more milk than without nipple shields. The mean transfer of milk without a shield was $3.9 \mathrm{~mL}$, compared to a mean of $18.4 \mathrm{~mL}$ with the shield, resulting in a $14.4 \mathrm{~mL}$ difference. These infants used the nipple shield for a mean duration of 33 days, which was a mean of $24.3 \%$ of the total breastfeeding experience (16) (Table 2).

\section{Mothers' Experiences}

Eight studies focused on the mothers' experiences with nipple shield use $(3,4,7,13,14,17-19)$. Of these studies, four were prospective $(3,13,18,19)$ and four were retrospective $(4,7,14,17)$.

Chertok et al. (18) conducted a prospective two-part pilot study. Part 1 consisted of 32 breastfeeding mother-infant dyads that had received support from lactation consultants and had used or were still using nipple shields. A structured telephone survey was used to examine maternal satisfaction with nipple shield use. The reasons for nipple shield use were for infant reasons $[16 / 32(50 \%)]$, maternal reasons $[12 / 32(37.5 \%)]$, and

TABLE 2 | Effects of nipple shield usage on premature infants.

\begin{tabular}{|c|c|c|c|}
\hline Author & Study population & Methods & Outcomes \\
\hline $\begin{array}{l}\text { Clum and } \\
\text { Primomo (2) }\end{array}$ & $\begin{array}{l}\text { - } 15 \text { premature infants } \\
\text { - } \quad \text { Patients at a NICU in South Puget } \\
\text { Sound } \\
\text { - } \text { Mothers intended to breastfeed }\end{array}$ & $\begin{array}{l}\text { - Charts were reviewed to identify } \\
\text { - Maternal parity } \\
\text { - Gestational age } \\
\text { - Birth weight } \\
\text { - } \text { Age of infant at first feed } \\
\text { - } \text { Age at introduction of nipple shield } \\
\text { - Infant age at discharge } \\
\text { - Prescribed amount of feeding was compared to the } \\
\text { actual intake by test weights } \\
\text { Mothers maintained their milk supply with a high- } \\
\text { quality, intermittent electric pump with a known } \\
\text { pressure } \\
\text { - Were advised to pump both breasts } \\
\text { simultaneously for } 10 \text { min, } 8 \text { times every } 24 \mathrm{~h}\end{array}$ & $\begin{array}{l}\text { - } \quad \text { Reasons for nipple shield use } \\
\text { - Had difficulty latching without the shield } \\
\text { - } \quad \text { Infants' an average of } 5 \text { days } \\
\text { nipple shield use: } 34.9 \text { weeks (range of } \\
\text { 33-39 weeks) } \\
\text { - } 9 \text { infants (60\%) consumed } \geq 50 \% \text { of the } \\
\text { prescribed feeding amount using a nipple } \\
\text { shield } \\
6 \text { infants consumed } 13-28 \% \text { of the } \\
\text { prescribed feeding amount using a nipple } \\
\text { shield }\end{array}$ \\
\hline $\begin{array}{l}\text { Meier } \\
\text { et al. (16) }\end{array}$ & $\begin{array}{l}\text { - } 34 \text { premature infants } \\
\text { - Were hospitalized in } 1 \text { of } 2 \text { hospitals } \\
\text { during a 12-month period in } \\
\text { 1997-1998 } \\
\text { - Mothers had used nipple shields to } \\
\text { facilitate milk intake during and/or } \\
\text { after each infant's stay in a NICU }\end{array}$ & $\begin{array}{l}\text { Volume of milk transfer, measured by infant } \\
\text { test-weights, was compared for } 2 \text { consecutive } \\
\text { breastfeeding with and without the nipple shield } \\
\text { - Total duration of nipple shield use and breastfeeding } \\
\text { were calculated } \\
\text { - Reasons for nipple shield use were recorded }\end{array}$ & 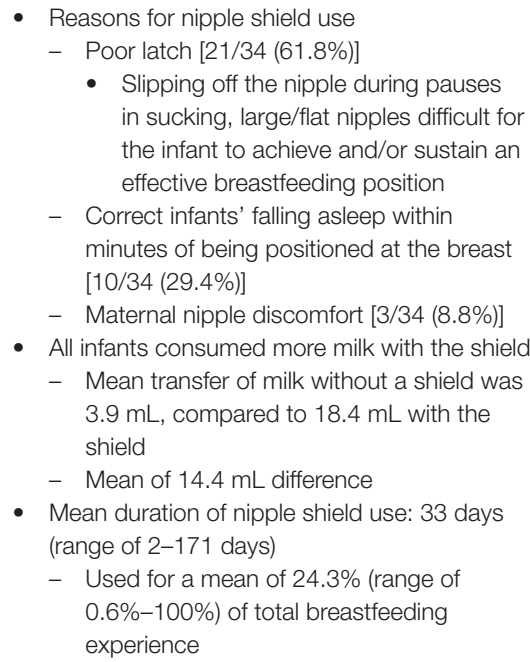 \\
\hline
\end{tabular}

mL, milliiter; NICU, neonatal intensive care unit. 
TABLE 3 | Mothers' experiences with nipple shield usage.

\begin{tabular}{|c|c|c|c|}
\hline Author & Study population & Methods & Outcomes \\
\hline $\begin{array}{l}\text { Bodley and } \\
\text { Powers (7) }\end{array}$ & - 10 mothers & - Chart reviews & 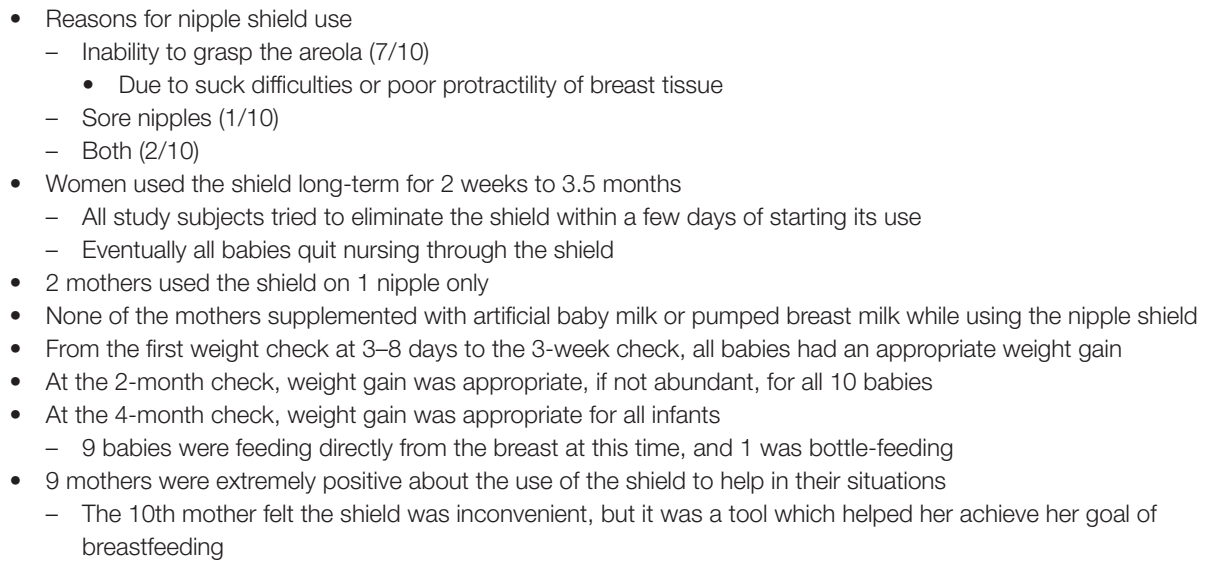 \\
\hline Brigham (14) & $\begin{array}{l}\text { - } 51 \text { clients of the Breastfeeding } \\
\text { Center at Evergreen Hospital } \\
\text { - Were given a nipple shield in } \\
1994 \\
\text { - Infant population included } \\
\text { healthy, term infants, premature } \\
\text { infants, and infants with Down } \\
\text { syndrome }\end{array}$ & $\begin{array}{l}\text { - Study subjects were interviewed } \\
\text { for an average of about } 10 \text { min by } \\
\text { telephone } \\
\text { - The following information was } \\
\text { documented } \\
\text { - Reason for nipple shield use } \\
\text { - } \text { Age of baby at first use } \\
\text { - Length of use } \\
\text { - Duration of breastfeeding (total } \\
\text { duration and duration after shield } \\
\text { discontinued) } \\
\text { - Helpfulness of the shield }\end{array}$ & 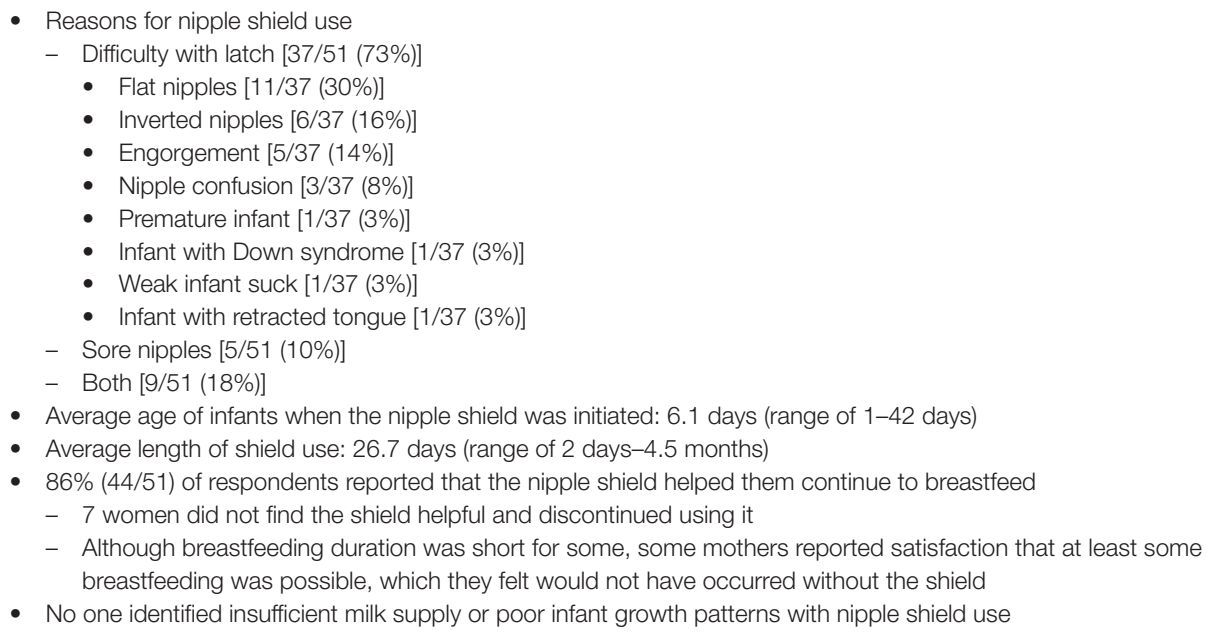 \\
\hline
\end{tabular}


TABLE 3 | Continued

\begin{tabular}{|c|c|c|}
\hline Author & Study population & Methods \\
\hline $\begin{array}{l}\text { Chertok et al. } \\
\text { (18) }\end{array}$ & $\begin{array}{l}\text { Part } 1 \\
\text { - } 32 \text { breastfeeding mother-infant } \\
\text { dyads } \\
\text { - } \text { Received support from lactation } \\
\text { consultants at Evergreen } \\
\text { Hospital or University of } \\
\text { Washington Medical Center } \\
\text { - Inclusion criteria } \\
\text { - Healthy postpartum women } \\
\text { - Knowledge of English } \\
- \text { Delivered by vaginal/ } \\
\text { cesarean delivery } \\
\text { - Had a healthy, full-term } \\
\text { ( } 37-42 \text { weeks) infant } \\
\text { singleton }\end{array}$ & 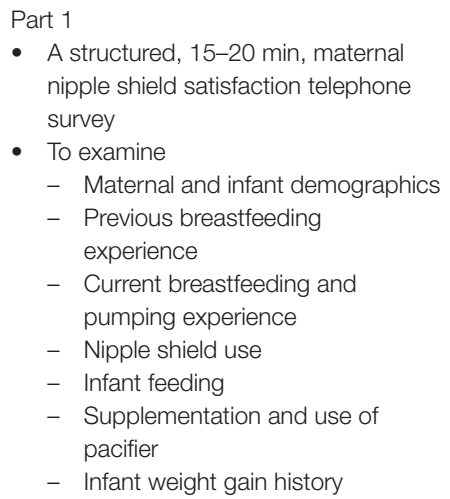 \\
\hline
\end{tabular}

utcomes

- A prospective within-subject design

- Practiced exclusive breastfeeding (no supplementation)

or nearly exclusive breastfeeding (minimal fluid supplementation)

- Had used/were still using Part 2 nipple shields

- 5 mother-infant dyads

- Had completed Part 1

- Were in the process of weaning from the nipple shield

physiological outcomes so examine materin and cortisol levels and infant test weights during 2 breastfeeding sessions with and without the nipple shield

- Hormone levels were analyzed by collecting 3 blood samples - Immediately before - $10 \mathrm{~min}$

- 20 min after breastfeeding commenced

Part 1

- Reasons for nipple shield use

- Infant reasons [16/32 (50\%)]

- Poor suck, poor latch, tongue displacement, etc.

- Maternal reasons [12/32 (37.5\%)]

Nipple pain, nipple trauma, breast engorgement, inverted/flat nipples, etc. - Both $[4 / 32(12.5 \%)]$

- Most women [26/32 (81.3\%)] reported having no nipple pain with nipple shield use

- Remaining women reported nipple soreness with use of the nipple shield

- $62.5 \%$ (20/32) of women reported no complications with nipple shield use

- $37.5 \%$ (12/32) of women reported that the nipple shield complicated breastfeeding - Types of complications

Nipple shield tended to fall off the breast (5/32)

- Inconvenience (3/32)

- Infant dependency on the shield (2/32)

- Infant swallowed too much air (2/32)

- Messiness (1/32)

- Average length of shield use: 7.3 days (range of 3-13 days)

- If they did not use the nipple shield

- 6 would terminate breastfeeding

- 6 would pump breast milk

- 16 would continue trying to breastfeed

- 4 expressed concerns over continued infant weight loss

Part 2

- Maternal prolactin and cortisol levels for breastfeeding sessions with and without the nipple shield were not significantly different

- No significant differences in the mean prolactin levels

- Levels significantly increased over time for breastfeeding with and without nipple shields

- No significant differences in the mean cortisol levels

- No significant change over time

- Levels with and without nipple shields followed similar trends over time

- No significant differences in maternal hormonal levels and infant breast milk intake for breastfeeding sessions with and without nipple shields 
TABLE 3 | Continued

\begin{tabular}{|c|c|c|c|}
\hline Author & Study population & Methods & Outcomes \\
\hline Chertok (3) & $\begin{array}{l}\text { - } 54 \text { mother-infant dyads } \\
\text { - From } 2 \text { major cities in USA and } \\
\text { Israel } \\
\text { - Inclusion criteria } \\
\text { - Healthy mothers } \\
\text { - Term, healthy infants } \\
\text { - Experience with } \\
\text { breastfeeding } \\
\text { - Experience using nipple } \\
\text { shields during the } \\
\text { postpartum period }\end{array}$ & $\begin{array}{l}\text { - Study subjects were interviewed with } \\
10 \text { questions by telephone } \\
\text { - To examine } \\
\text { - Lactation practices } \\
\text { - Nipple shield use } \\
\text { - Infant weight gain over } 2 \text { months } \\
\text { postpartum } \\
\text { - Maternal satisfaction } \\
\text { - Mothers were surveyed at birth and } \\
2 \text { weeks, } 1 \text { month, and } 2 \text { months } \\
\text { postpartum }\end{array}$ & 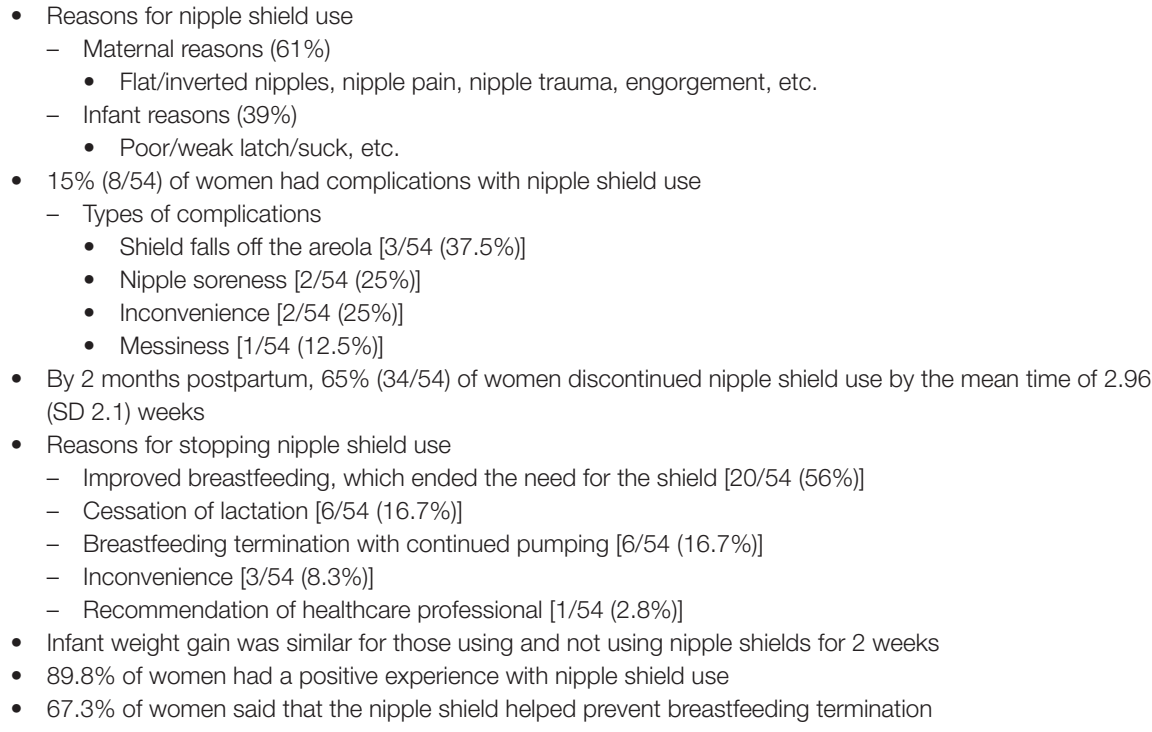 \\
\hline Nicholson (13) & $\begin{array}{l}\text { - Study population was divided } \\
\text { into } 3 \text { groups } \\
\text { "NS" } \\
\text { - } 186 \text { mothers } \\
\text { - Seen by the hospital lactation } \\
\text { consultant before discharge } \\
\text { - Were using nipple shields } \\
\text { "No NS" } \\
\text { - } 636 \text { mothers } \\
\text { - Seen by the hospital lactation } \\
\text { - } \quad \text { Wensultant before discharge } \\
\text { "PN" } \\
\text { - } 349 \text { breastfeeding postnatal } \\
\text { mothers } \\
\text { - Not seen by the lactation } \\
\text { consultant }\end{array}$ & $\begin{array}{l}\text { - Collected data from all } 3 \text { groups } \\
\text { before hospital discharge and } \\
3 \text { months postpartum, during } 1988 \\
\text { and } 1989 \\
\text { - A 3-month interview was carried out } \\
\text { by telephone or a questionnaire was } \\
\text { sent by mail } \\
\text { - Following information was recorded } \\
\text { - Feeding method at } 3 \text { months } \\
\text { - Problems (mastitis and nipple trauma) } \\
\text { experienced between hospital } \\
\text { discharge and } 3 \text { months }\end{array}$ & $\begin{array}{l}\text { - Breastfeeding rates on discharge } \\
\text { - "NS": } 95 \%(176 / 186) \\
\text { - "No NS": 83\% (530/636) } \\
\text { - "PN": } 91 \%(318 / 349) \\
\text { - Breastfeeding continuation rates at } 3 \text { months postpartum } \\
\text { - "NS": } 55 \%(92 / 166) \\
\text { - } 51 \% \text { exclusively (84/166) } \\
\text { - "No NS": 63\% (298/473) } \\
\text { - } 54 \% \text { exclusively (256/473) } \\
\text { - "PN": } 67 \%(190 / 282) \\
\text { - } 57 \% \text { exclusively (161/282) } \\
\text { - "NS": } 13 \text { out of the } 92 \text { women breastfeeding at } 3 \text { months were still using nipple shields } \\
\text { - } \text { All of these women were breastfeeding exclusively } \\
\text { - } 7 \text { women used the nipple shield for their entire lactation } \\
\text { - Breastfeeding problems at } 3 \text { months postpartum } \\
\text { - "NS": } 9 \%(15 / 166) \text { - nipple trauma; } 12 \%(20 / 166) \text { - mastitis } \\
\text { - "No NS": 6\% (27/473) - nipple trauma; 8\% (40/473) - mastitis } \\
\text { - "PN": } 7 \%(19 / 282) \text { - nipple trauma; } 7 \%(19 / 282) \text { - mastitis }\end{array}$ \\
\hline
\end{tabular}


Pincombe et al. • 317 women

(19)

- Had given birth to their first baby (at term) in a large teaching maternity hospital in Adelaide, South Australia, between March and November 2003

\section{- Inclusion criteria}

- Women $\geq 18$ years of age

- Primiparous

- $\geq 37$ weeks gestation

- Intending to breastfeed

- Able to understand and communicate in both written and spoken English

Powers, Tapia - 202 breastfeeding women
- BFHI Step 9 (giving no artificial teats/ pacifiers to breastfeeding babies) was investigated during telephone interviews

- 3 separate questions relating to the use of nipple shields, pacifiers dummies, and bottle-feeds at 1 week, 6 weeks, 3 months, and 6 months postpartum

- Participants were asked if they were still breastfeeding, and if they were breastfeeding fully (breast milk only) or partially (formula and/or solids and breast milk)

- If baby had been weaned, the mother was asked the age of her baby (to the nearest week) when he/she was weaned

- 10 min telephone survey assessing mothers' perceptions regarding use of a silicone nipple shield and its impact on their breastfeeding experience

- Data obtained were based on subjective recall of the women interviewed
- $14.2 \%$ of mothers used a nipple shield while in the postnatal ward, while $85.8 \%$ did not

- Higher rate of weaning was found among mothers who used artificial nipples, including nipple shields, compared to those who offered the breast exclusively

- Breastfeeding duration was shorter for mothers who did not experience all of the BFHI practices (e.g., using no artificial nipples including a nipple shield, feeding $>1 \mathrm{~h}$ of birth, receiving feeding assistance, giving only breast milk to the infant, rooming-in) compared to those women who experienced all of these practices

- Unadjusted hazard ratio for weaning is 2.1 times greater for babies whose mothers used nipple shields compared with those who did not

- 1.6 times greater for babies offered dummies/pacifiers while in the postnatal ward

- 1.4 times greater for babies given a bottle feed

- Increased hazard of weaning was found for mothers who were shown how to initiate breastfeeding by the midwife

- Breastfeeding on demand while in hospital had a significantly increased risk of weaning

- Reasons for nipple shield use

- Short/flat nipples [125/202 (62\%)]

- Infant's disorganized suck [88/202 (43\%)]

- Sore nipples [49/202 (23\%)]

- Engorgement [31/202(15\%)]

- Prematurity $[25 / 202(12 \%)]$

- Short frenulum $[4 / 202(1 \%]$

- Other reasons [3/202 (1\%)]

- Infant with a receding chin

- Protecting burn scars on the mother's areola

- A mother who believed her infant's difficulty with latch were because of her infant's later diagnosed autism

- $46 \%$ of women gave $>1$ reason for using a shield

- Nipple shield use began the 1 st-42nd day of the infant's life

- $60 \%(122 / 202)$ began nipple shield use on the first or second day after delivery

- 97\% (197/202) began within the first 2 weeks postpartum

- Median duration of nipple shield use: 2 weeks

- One third (67/202) used the nipple shield the entire time they breastfed (range of 1 day-15 months)

- 92 women were given information regarding the shields for flat, inverted, or sore nipples

- $67 \%(62 / 92)$ of these women chose to wear the shields

- Only $51 \%$ of these 62 women believed that wearing them helped them to succeed at breastfeeding

- Those who did not believe they were helpful commented that the nipple shields were uncomfortable

- This was especially true after milk onset occurred, usually the third or fourth day postpartum, and the shields exacerbated leaking

- $11 \%(22 / 202)$ of the women reported that the infant could have nursed without the nipple shield at any time but they chose to use the shield for nipple pain or general comfort

- $5 \%$ of women used the nipple shield on only one nipple

- $88 \%(178 / 202)$ of mothers felt that the nipple shield helped them succeed at breastfeeding 
both maternal and infant reasons [4/32 (12.5\%)]. Overall, mothers were satisfied with nipple shields and attributed its use with preventing early weaning (18) (Table 3). This study's second part used a within-subject design to evaluate maternal prolactin and cortisol levels and infant test weights during two breastfeeding sessions, one with and one without the nipple shield. The study population included five maternal-infant dyads that had completed Part 1 and were in the process of weaning from nipple shield use. Based on blood samples collected immediately before, and 10 and 20 min after breastfeeding started, maternal hormone levels were not significantly different for breastfeeding sessions with and without the nipple shield (prolactin $-p=0.88$; cortisol $-p=0.74)$. Similarly, there were no significant differences in infant breast milk intake for breastfeeding sessions with and without nipple shields $(p=0.72)$. Therefore, nipple shields were an effective intervention strategy that did not affect milk transfer or hormone levels and could prevent early breastfeeding termination (18) (Table 3).

Chertok (3) conducted another telephone survey in 2009, which involved 54 maternal-infant dyads from the United States of America and Israel, who had experienced nursing with and without nipple shields during the postpartum period. Mothers were surveyed at birth and 2 weeks, 1 month, and 2 months postpartum in order to determine how nipple shield use affected infant weight gain. Reasons for nipple shield use were mostly maternally related (61\%) but also sometimes infant related (39\%). Infant weight gain was similar for those using and not using nipple shields at the 2 -week survey ( $p=0.30$ and $p=0.16$, respectively). In total, $89.8 \%$ of mothers had a positive experience with nipple shields and $67.3 \%$ credited the nipple shields for prevention of breastfeeding discontinuation (3) (Table 3).

Nicholson (13) conducted a prospective study in which the study population was divided into three groups: "NS" - 186 mothers who were seen by the hospital lactation consultant and were given nipple shields; "No NS" - 636 mothers who were seen by the hospital lactation consultant and were not given nipple shields; "PN" - 349 breastfeeding postnatal mothers who were not seen by the lactation consultant. Data were collected from all groups before hospital discharge and at 3 months postpartum. A 3-month interview was carried out by telephone or a questionnaire was sent by mail to investigate the feeding method at 3 months and problems experienced between hospital discharge and 3 months postpartum. Although "No NS" mothers had a much lower breastfeeding rate on discharge than the "NS" group $(p<0.001)$, this significant difference disappeared at 3 months postpartum. Since there were not any significant differences in breastfeeding rates at 3 months between the "NS" and "No NS" group, nipple shield use was not considered to have negative effects on lactation. Significantly fewer "NS" mothers were breastfeeding at 3 months (55\%) than those in the "PN" group (67\%) $(p=0.01)$ It was found that more than half of the women in each group continued breastfeeding at 3 months, and the majority were breastfeeding exclusively. There was a small proportion of mothers in all groups who experienced nipple trauma and mastitis at 3 months; the "NS" group had the highest rates of breastfeeding problems, followed by "No NS" and "PN." Therefore, use of a nipple shield did not impede breastfeeding initiation (13) (Table 3). 
In a final prospective study, Pincombe et al. (19) assessed the effects of Baby Friendly Hospital Initiative (BFHI) procedures on breastfeeding duration. Three hundred seventeen mothers who were intending to breastfeed and had given birth to their first at term baby in an Australian hospital were included in the study. BFHI Step 9, which is to restrain from giving artificial teats/ pacifiers to breastfeeding babies, was analyzed through telephone interviews consisting of three separate questions. A total of $14.2 \%$ of participants used a nipple shield while in the postnatal ward. A higher rate of weaning was found among mothers who used artificial nipples (e.g., nipple shields) compared to mothers who offered the breast exclusively. Other factors that led to increased risks of breastfeeding termination were breastfeeding on demand in hospital and midwives teaching mothers how to initiate breastfeeding. Similarly, breastfeeding duration was shorter for women who did not experience all of the BFHI practices (19) (see Table 3).

Four retrospective studies comprised two chart reviews and two telephone surveys $(4,7,14,17)$.

Boldey and Powers (7) conducted chart reviews for 10 mothers who used nipple shields. The reasons for nipple shield use were the baby's inability to grasp the areola (7/10), nipple soreness $(1 / 10)$, and both of the aforementioned causes $(2 / 10)$. The duration of shield use ranged from 2 weeks to 3.5 months, and all infants eventually quit nursing through the shield. All babies had appropriate weight gain at the 3-8 day, 3 week, 2 month, and 4 month weight check. Nine mothers were extremely positive about using the nipple shield to help in their situations, while one woman felt the shield was inconvenient, but she admitted that the tool helped her breastfeed (7) (see Table 3).

Wilson-Clay (4) also performed chart reviews for 32 women who received nipple shields from a lactation clinic. The most common problems at consultation were breast refusal (69\%), difficulty with latch $(25 \%)$, and sore nipples $(6 \%)$. The duration of shield use varied among the study population. A total of $38 \%$ of mothers (12/32) weaned nipple shield use during the initial crisis period ( $<6$ weeks), 56\% (18/32) weaned after 6 weeks, and $6 \%(2 / 32)$ of women fed their infants human milk by bottle (4) (see Table 3).

Brigham (14) interviewed 51 clients of the Breastfeeding Center at Evergreen Hospital, who were given a nipple shield by telephone. The reasons for nipple shield use included difficulty with latch [37/51 (73\%)], sore nipples [5/51 (10\%)], and both of the aforementioned causes [9/51 (18\%)]. The average age of infants when the nipple shield was first used was 6.1 days, ranging from 1 to 42 days, and the average length of shield use was 26.7 days, ranging from 2 days to 4.5 months. The majority of respondents [44/51 (86\%)] reported that the nipple shield helped them continue to breastfeed. None of the women surveyed identified insufficient milk supply or poor infant growth patterns with nipple shield use (14) (see Table 3).

Powers and Tapia (17) conducted a telephone survey that assessed mothers' perceptions regarding use of a nipple shield and its impact on their breastfeeding experience. Two hundred two women who had discontinued nipple shield use for at least 1 week at the time of the survey were included in this study. The reasons for nipple shield use included short or flat nipples [125/202 (62\%)], infant's disorganized suck [88/202 (43\%)], and sore nipples [49/202 (23\%)], with $46 \%$ of mothers giving more than one reason for using a shield. Nipple shield use began between the 1st and 42nd day of the infant's life, and the median duration of use was 2 weeks. A total of $11 \%(22 / 202)$ of mothers reported that the infant could have nursed without the nipple shield at any time, but they chose to use the shield for nipple pain or general comfort. Almost all of the women surveyed [178/202 (88\%)] felt that the nipple shield helped them succeed at breastfeeding (17) (see Table 3).

\section{Health Professionals' Experiences}

One study reported the health professionals' experiences with nipple shield use (20). Eglash et al. (20) created a web-based survey to collect detailed descriptive data from respondents who work with breastfeeding mothers in diverse settings. The study population consisted of 490 physicians and other health professionals specialized in breastfeeding management, 92\% (451/490) of whom had used nipple shields in their practices before. Their most common reasons for recommending nipple shield use were to help $<35$ weeks premature infants latch and nurse, to accommodate flat or inverted nipples, and to act as a method to transition an infant from bottles to the breast. The most common concerns among participants about nipple shield use were the "lack of follow-up by those introducing the nipple shield," "inappropriate reasons for using nipple shields," and "maternal inconvenience of using nipple shields." Respondents reported that they hear mixed responses from women who have used nipple shields, such as "they are helpful," "the nipple shield is convenient," "the nipple shield is inconvenient," and "(they) cannot wait to get rid of the nipple shield” (20) (see Table 4).

\section{DISCUSSION}

There are many benefits to nipple shields. The use of a nipple shield can maintain breastfeeding, along with providing the mother a sense of accomplishment $(2,14)$. This ensures that the infant is comfortable and oriented to the breast (14). Additionally, nipple shields can help establish a breastfeeding relationship, contributing to overall mother-infant health (2). Brigham has found that nipple shields tend to be the least costly solution both financially and emotionally to families. As well, the shield is not seen when breastfeeding, enabling mothers and their babies to resemble any other nursing team. This appearance can be crucial to new parents who need a simple and discreet feeding plan (14).

Moreover, nipple shields can compensate for immature feeding behaviors, such as short, ineffective sucking bursts and falling asleep immediately after being positioned at the breast in premature infants $(16,21)$. The design of the nipple shield seems to compensate for weak intraoral suction pressures (16). Since the shield creates a nipple shape in the baby's mouth, it enables the infant to draw milk through expression with minimal suction, improving milk ejection and transfer. The firm artificial nipple structure is maintained even during pauses in sucking bursts, 
TABLE 4 | Health professionals' experiences with nipple shield usage.

\begin{tabular}{|c|c|c|c|}
\hline Author & Study population & Methods & Outcomes \\
\hline Eglash et al. (20) & $\begin{array}{l}\text { - } 490 \text { physicians and other health } \\
\text { professionals specialized in } \\
\text { breastfeeding management } \\
\text { - } \text { Most respondents were board } \\
\text { certified in lactation [412/490 (79\%)] } \\
\text { - } \quad \text { Most prevalent occupations } \\
\text { - } \quad \text { Lactation consultants [270/490 } \\
\quad(52 \%)] \\
\text { - } \text { Nurses [125/490 (24\%)] } \\
\text { - Physicians [43/490 (8\%)] } \\
\text { - La Leche League Leader [29/490 } \\
\text { - } 6 \% \text { ) } 92 \%(451 / 490) \text { of participants have } \\
\text { used nipple shields in their practices }\end{array}$ & $\begin{array}{l}\text { - A web-based anonymous survey was } \\
\text { advertised via internet } \\
\text { - } \text { Remained available online for a period of } \\
3 \text { weeks } \\
\text { - Collected detailed descriptive data from } \\
\text { respondents who work with breastfeeding } \\
\text { mothers in diverse settings } \\
\text { - Data from the survey were based on subjective } \\
\text { recall of the health prof essionals' experiences } \\
\text { with nipple shields } \\
\text { - Subjects were asked about } \\
\text { - Their most common reasons for } \\
\text { recommending nipple shield use } \\
\text { - Their most common concerns about nipple } \\
\text { shield use } \\
\text { - What they typically hear from breastfeeding } \\
\text { women who have used nipple shields }\end{array}$ & $\begin{array}{l}\text { - Reasons for nipple shield use } \\
\text { - } \quad \text { To help <35 weeks premature infants } \\
\text { latch and nurse } \\
\text { - } \text { Flat/inverted nipples (16\%) } \\
\text { - } \text { Method to transition an infant from } \\
\text { - bottles to breast (14\%) } \\
\text { - Concerns for nipple shield use } \\
\text { - "Lack of follow-up by those } \\
\text { introducing the nipple shield" } \\
\text { - "Inappropriate reasons for using } \\
\text { - nipple shields" } \\
\text { - } \text { naternal inconvenience of using } \\
\text { Maternal responses for nipple shield use } \\
\text { - "They are helpful" } \\
\text { - "The nipple shield is convenient" } \\
\text { - "The nipple shield is inconvenient" } \\
\text { - "Cannot wait to get rid of the nipple } \\
\text { shield" }\end{array}$ \\
\hline
\end{tabular}

ensuring that the baby stays attached to the nipple and does not slip off. Furthermore, once the shield is correctly positioned over the nipple and the infant begins to suck, negative pressure seems to be produced in the chamber between the maternal nipple's tip and the shield's interior. These pressures may balance out the infant's weak suck and allow the milk to be accumulated in the shield during pauses in sucking, which will then be available to the baby immediately when sucking continues (16). Resultantly, shield use increases both the duration of sucking bursts and the volume of milk consumed during breastfeeding for babies born prematurely (22). In addition, after experiencing a difficult pregnancy which ended in a preterm birth and consequent hospitalization and separation of the baby from the family, many mothers of premature infants want to breastfeed (2). By helping these mothers breastfeed their infants, perhaps with the help of a nipple shield, they receive one expected and planned outcome of their pregnancy (2).

However, there are widespread negative attitudes toward nipple shields. In a breastfeeding guide for healthcare professionals, it states that "Many lactation experts consider the use of a [nipple] shield a sign of failure of proper lactation guidance" (23). There are three main reasons for discouraging nipple shield use: (1) nipple shields are thought to reduce milk transfer from the mother to the infant and prevent complete breast emptying; (2) they are considered addictive, such that infants may prefer the nipple shield rather than the breast, making it difficult to terminate its use; (3) incomplete breast emptying and an infant's addiction to nipple shields is perceived to decrease the mother's milk yield over time, causing early unplanned weaning (16). Other philosophical and scientific concerns include its similarities with bottles by acting as an artificial barrier between the infant and the breast (16); its support for an industry that makes breastfeeding "unnatural" (16); poor growth patterns in infants (24); prevention of the proper extension of the nipple back into the baby's mouth, which might interfere with learning to suckle correctly (25); improper introduction of a shield to feed a baby before hospital discharge $(11,24)$; cause or worsening of sore nipples $(11,24)$; possible nipple trauma from pinching of the nipple and areola, especially with misuse (26); as well as reduced stimulation of the areola, which may interfere with prolactin and oxycotin release (24). Evidently, nipple shields remain a controversial issue in both the literature and clinical settings.

The reasons for varying durations of nipple shield use are not clear. It seems that a woman's perception of her baby's ease or difficulty with breastfeeding plays a role in the length of use of nipple shields. Some mothers have low tolerance for witnessing her infant struggle at the breast. Equivalently, women have different pain tolerances and abilities to cope with stress, which impacts how they deal with nipple soreness (7). Powers and Tapia discovered that a woman's frustration with nipple shield use tends to be exceeded by the frustration of an infant that is unable to latch or that causes severe nipple pain (17).

Healthcare professionals should include evaluation of mothers' nipples for elasticity during pregnancy and in the postpartum period to screen for and identify women at risk for lactation difficulty (4). In order to prevent potential inappropriate nipple shield use, clinical staff (e.g., nurses, neonatologists, pediatricians, lactation consultants) and parents need to be educated about the benefits and risks of nipple shields, newborn recovery, early breastfeeding, and elimination patterns versus genuine breastfeeding problems. Parents should be provided with early follow-up and resource phone numbers for breastfeeding assistance, which is especially important when in-hospital care is short (14). Likewise, public health should implement improved postdischarge support services and/or interventions that improve opinions toward breastfeeding in socio-cultural and economic groups to promote and encourage longer durations of breastfeeding (19). Care providers should also include the mother in the decision-making process, allowing her to make the choice that is the most beneficial for her and her infant (17).

The goal of lactation management is to offer individualized care and solutions leading to continued breastfeeding (14). For 
each problem, several paths may result in successful breastfeeding. Follow-up is the key to any lactation strategy. When lactation tools or techniques are initiated, including nipple shields, follow-up is necessary to assess the plan's effectiveness, progress toward resolving the problem, and mother-infant satisfaction and comfort (14).

\section{REFERENCES}

1. Cunningham AS, Jelliffe DB, Jelliffe EF. Breast-feeding and health in the 1980s: a global epidemiologic review. J Pediatr (1991) 118:659-66. doi:10.1016/ S0022-3476(05)80023-X

2. Clum D, Primomo J. Use of a silicone nipple shield with premature infants. $J$ Hum Lact (1996) 12(4):287-90. doi:10.1177/089033449601200413

3. Chertok IRA. Reexamination of ultra-thin nipple shield use, infant growth and maternal satisfaction. J Clin Nurs (2009) 18:2949-55. doi:10.1111/j.1365-2702.2009.02912.x

4. Wilson-Clay B. Clinical use of silicone nipple shields. J Hum Lact (1996) 12(4):279-85. doi:10.1177/089033449601200412

5. McKechnie AC, Eglash A. Nipple shields: a review of the literature. Breastfeed Med (2010) 5(6):309-14. doi:10.1089/bfm.2010.0003

6. Riordan J, Auerbach K. Breastfeeding and Human Lactation. Sudbury, MA: Jones Bartlett (2009). p. 407-8.

7. Bodley V, Powers D. Long-term nipple shield use: a positive perspective. $J$ Hum Lact (1996) 12(4):301-4. doi:10.1177/089033449601200416

8. Meier PP, Furman LM, Degenhardt M. Increased lactation risk for late preterm infants and mothers: evidence and management strategies to protect breastfeeding. J Midwifery Womens Health (2007) 52:579-87. doi:10.1016/j. jmwh.2007.08.003

9. Woolridge MW, Baum JD, Drewett RF. Effect of a traditional and of a new nipple shield on sucking patterns and milk flow. Early Hum Dev (1980) 4(4):357-64. doi:10.1016/0378-3782(80)90040-7

10. Amatayakul K, Vutyavanich T, Tanthayaphinant O, Tovanabutra S, Yutabootr Y, Drewett RF. Serum prolactin and cortisol levels after suckling for varying periods of time and the effect of a nipplesShield. Acta Obstet Gynecol Scand (1987) 66:47-51. doi:10.3109/00016348709092953

11. Jackson DA, Woolridge MS, Imong SM, McLeod CN, Yutabootr Y, Wongsawat L, et al. The automatic sampling shield: a device for sampling suckled breast milk. Early Hum Dev (1987) 15:295-306. doi:10.1016/0378-3782(87)90052-1

12. Auerbach KG. The effect of nipple shields on maternal milk volume. J Obstet Gynecol Neonatal Nurs (1990) 19(5):419-27. doi:10.1111/j.1552-6909.1990. tb01661.x

13. Nicholson WL. The use of nipple shields by breastfeeding women. Aust Coll Midwives Inc J (1993) 6:18-24.

14. Brigham M. Mothers' reports of the outcome of nipple shield use. J Hum Lact (1996) 12(4):291-7. doi:10.1177/089033449601200414

15. Elliott C. Using a silicone nipple shield to assist a baby unable to latch. J Hum Lact (1996) 12(4):309-13. doi:10.1177/089033449601200418
The findings from this review are very important in the field of lactation in many ways. Through examining the use of nipple shields, further insight is provided on the advantages and disadvantages of this practice, thus allowing clinicians and researchers to address improvements on areas that will benefit mothers and infants the most.

16. Meier PP, Brown LP, Hurst NM, Spatz DL, Engstrom JL, Borucki LC, et al. Nipple shields for preterm infants: effect of milk transfer and duration of breastfeeding. J Hum Lact (2000) 16(2):106-14 doi:10.1177/089033440001600205

17. Powers D, Tapia VB. Women's experiences using a nipple shield. J Hum Lact (2004) 20(3):327-34. doi:10.1177/0890334404267214

18. Chertok IR, Schneider J, Blackburn S. A pilot study of maternal and term infant outcomes associated with ultrathin nipple shield use. J Obstet Gynecol Neonatal Nurs (2006) 35(2):265-72. doi:10.1111/j.1552-6909.2006.00028.x

19. Pincombe J, Baghurts P, Antoniou G, Peat B, Henderson A, Reddin E, et al. Baby friendly hospital initiative practices and breast feeding duration in a cohort of first-time mothers in Adelaide, Australia. Midwifery (2008) 24:55-61. doi:10.1016/j.midw.2006.06.009

20. Eglash A, Ziemer AL, McKechnie AC. Health professionals' attitudes and use of nipple shields for breastfeeding women. Breastfeed Med (2010) 5(4):147-51. doi:10.1089/bfm.2010.0006

21. Meier PP. Professional Guide to Breastfeeding Premature Infants. Columbus, OH: Ross Laboratories (1997).

22. Spatz D. Nipple shields for preterm infants: breastfeeding outcomes. Paper Presented at: $4^{\text {th }}$ Annual Lactation Conference for Advanced Practitioners; Oak Brook, IL: Rush College of Nursing (1998).

23. Lawrence RA, Lawrence RM. Breastfeeding: A Guide for the Medical Profession. 5th ed. St Louis, MO: Mosby (1999).

24. Walker M, Auerbach KG. Breast pumps and other technologies. In: Riordan J, Auerbach KG, editors. Breastfeeding and Human Lactation. Boston, MA: Jones Bartlett (1993). p. 311-22.

25. Minchin M. Breastfeeding Matters. Victoria; Alma Publications (1989). 142 p.

26. Riordan J. Breastfeeding and Human Lactation. 3rd ed. Boston, MA: Jones Bartlett (2005).

Conflict of Interest Statement: The authors declare that the research was conducted in the absence of any commercial or financial relationships that could be construed as a potential conflict of interest.

Copyright (C) 2015 Chow, Chow, Popovic, Lam, Merrick, Ventegodt, Milakovic, Lam, Popovic, Chow and Popovic. This is an open-access article distributed under the terms of the Creative Commons Attribution License (CC BY). The use, distribution or reproduction in other forums is permitted, provided the original author(s) or licensor are credited and that the original publication in this journal is cited, in accordance with accepted academic practice. No use, distribution or reproduction is permitted which does not comply with these terms. 